Article

\title{
Catechol 1,2-Dioxygenase is an Analogue of Homogentisate 1,2-Dioxygenase in Pseudomonas chlororaphis Strain UFB2
}

\author{
Boitumelo Setlhare ${ }^{\circledR}$, Ajit Kumar, Mduduzi P. Mokoena and Ademola O. Olaniran * \\ Discipline of Microbiology, School of Life Sciences, College of Agriculture, Engineering and Science, \\ University of KwaZulu-Natal (Westville Campus), Private Bag X54001, Durban 4000, South Africa; \\ boitumellow5@gmail.com (B.S.); ajitkanwal@yahoo.com (A.K.); Mokoenap@ukzn.ac.za (M.P.M.) \\ * Correspondence: olanirana@ukzn.ac.za; Tel.: +27-31260-7400
}

Received: 11 October 2018; Accepted: 29 November 2018; Published: 24 December 2018

check for updates

\begin{abstract}
Catechol dioxygenases in microorganisms cleave catechol into cis-cis-muconic acid or 2-hydroxymuconic semialdehyde via the ortho- or meta-pathways, respectively. The aim of this study was to purify, characterize, and predict the template-based three-dimensional structure of catechol 1,2-dioxygenase (C12O) from indigenous Pseudomonas chlororaphis strain UFB2 (PcUFB2). Preliminary studies showed that $P c$ UFB2 could degrade 40 ppm of 2,4-dichlorophenol (2,4-DCP). The crude cell extract showed $10.34 \mathrm{U} / \mathrm{mL}$ of $\mathrm{C} 12 \mathrm{O}$ activity with a specific activity of $2.23 \mathrm{U} / \mathrm{mg}$ of protein. A $35 \mathrm{kDa}$ protein was purified to 1.5 -fold with total yield of $13.02 \%$ by applying anion exchange and gel filtration chromatography. The enzyme was optimally active at $\mathrm{pH} 7.5$ and a temperature of $30^{\circ} \mathrm{C}$. The Lineweaver-Burk plot showed the $v_{\max }$ and $K_{\mathrm{m}}$ values of $16.67 \mu \mathrm{M} / \mathrm{min}$ and $35.76 \mu \mathrm{M}$, respectively. ES-MS spectra of tryptic digested SDS-PAGE band and bioinformatics studies revealed that $\mathrm{C} 12 \mathrm{O}$ shared $81 \%$ homology with homogentisate 1,2-dioxygenase reported in other Pseudomonas chlororaphis strains. The characterization and optimization of $\mathrm{C} 12 \mathrm{O}$ activity can assist in understanding the 2,4-DCP metabolic pathway in PcUFB2 and its possible application in bioremediation strategies.
\end{abstract}

Keywords: catechol 1,2-dioxygenase; homogentisate 1,2-dioxygenase; Pseudomonas chlororaphis; Pseudomonas chlororaphis strain UFB2

\section{Introduction}

The widespread distribution of aromatic compounds in the environment has led to an increase in pollution, which affects the health quality of living organisms [1]. Microorganisms have developed mechanisms to degrade these compounds with the aid of enzymes [2,3]. During the aerobic biodegradation of aromatic compounds, phenol, and it derivatives (e.g., 2,4-dichlorophenoxacetic acid (2,4-D) and 2,4-dichlorophenol (2,4-DCP)), catechols are formed as the central intermediates by the introduction of hydroxyl groups facilitated at ortho- or meta-positions [4-6]. The catechol is then oxidized via an ortho-cleavage pathway by catechol 1,2-dioxygenase (C12O), or via a meta-pathway to 2-hydroxymuconic semialdehyde by catechol 2,3-dioxygenase $(\mathrm{C} 23 \mathrm{O})$ to open the ring. The final intermediates of both pathways then enter the tricarboxylic acid cycle [7-9].

Catechol 1,2-dioxygenases have the potential to be used in the process of remediating wastewater contaminated with phenol, benzoate, fluorocatechol, bromocatechol, chlorocatechol, methylcatechol, herbicides (diuron), polychlorinated biphenyls, and chloroethanes [10,11]. The enzyme incorporates an oxygen atom into the catechol, resulting in the formation of cis-cis-muconic acid [12,13]. C12O is mostly reported in Gram-negative bacteria, but much less information is available about these enzymes 
in Gram-positive bacteria [10,12]. C12O contains Iron(III) oxide as a prosthetic group, and it is part of the enzymes that cleave catechol via the ortho-cleavage, resulting in the formation of cis-cis-muconic acid [14].

$\mathrm{C} 12 \mathrm{O}$ was first isolated and purified in Pseudomonas spp. found to be dependent on $\mathrm{Fe}^{2+}$ and $\mathrm{Fe}^{3+}$ ions with high substrate specificity, showing molecular weight ranges from 22 to $35 \mathrm{kDa}[13,15]$. Pseudomonas aeruginosa TKU002 capable of mineralizing benzoic acid was reported to produce a low molecular weight $\mathrm{C} 12 \mathrm{O}$ showing the highest activity against pyrogallol, which is an unusual characteristic $[13,15]$. Trichosporon sp. is reported to produce a high molecular weight C12O (100 kDa) that is stable at $\mathrm{pH} 8$ but optimally active at $\mathrm{pH} 6.2$ [13]. A non-heme ferric dioxygenase catalyzing the intradiol cleavage of all the examined catechol derivatives, 3,5-dichlorocatechol, was reported in Pseudomonas cepacia CSV90, grown with 2,4-D as the sole carbon source [16].

Enrichment studies on indigenous 2,4-DCP-degrading isolates from contaminated sites in Durban, South Africa showed an enormous potential to utilize 2,4-DCP as the sole carbon and energy source (unpublished data). The isolated culture was identified as Pseudomonas chlororaphis strain UFB2 (PcUFB2) and found to exhibit phenol hydroxylase, catechol 1,2-dioxygenase, muconate isomerase, cis-dienelactone hydrolase, and trans-dienelactone hydrolase activities (unpublished data).

Catechol, the intermediate in phenolic compound degradation pathways in bacteria, is also a derivative of benzene and a phenolic compound in many industrial applications, including as a photographic developer, lubricating oil, polymerization inhibitor, and in pharmaceuticals $[17,18]$. Catechol has a strong aroma and is a toxic and persistent water pollutant in the environment [17]. Thus, the aim of this study was to purify and characterize $\mathrm{C} 12 \mathrm{O}$ in PcUFB2 to understand the catalytic mechanism of the enzyme and predict its three-dimensional structure, for possible application of the enzyme in the removal of catechol from contaminated sites.

\section{Results}

\subsection{Production and Purification of $\mathrm{C} 12 \mathrm{O}$}

For the production of $\mathrm{C} 12 \mathrm{O}, 5 \mathrm{~L}$ medium was inoculated with $10 \%$ culture inoculum and $600 \mathrm{ppm}$ phenol was added as an inducer. The crude extract incubated with catechol did not show any absorbance at OD375 $\mathrm{nm}$ (detection of 2-hydroxymuconic semialdehyde) in contrast to an increased absorbance at OD260 $\mathrm{nm}$ (detection of cis-cis-muconic acid). The results concluded that the crude cell extract exhibited catechol 1,2-dioxygenase activity. Using the extinction coefficient of $14,800 \mu \mathrm{M} / \mathrm{min} / \mathrm{cm}$ for muconic acid described above, the OD at $260 \mathrm{~nm}$ was converted to $\mu \mathrm{M}$ of product released. Thus, the specific activity of $\mathrm{C} 12 \mathrm{O}$ from the crude extract was found to be $2.23 \mathrm{U} / \mathrm{mg}$ of protein. The crude cell extract concentrated and loaded in an ANX anion exchange purification column showed peaks at OD $=280 \mathrm{~nm}$ (Supplementary Material Figure S1). The fractions showing enzyme activity were pooled together, concentrated using a spin column, and again loaded on a gel filtration chromatography column packed with a Sephacryl HR100 matrix. Fractions A1 and A2 were collected and assayed for $\mathrm{C} 12 \mathrm{O}$ activity (Supplementary Material Figure S2). Fractions A1 and A2 showed the presence of single-band protein on SDS-PAGE (Figure 1). The protein purified to 1.5-fold showed a specific activity of $2.02 \mathrm{U} / \mathrm{mg}$ of protein (Table 1 ).

Table 1. Purification of catechol 1,2-dioxygenase (C12O) from Pseudomonas chlororaphis strain UFB2 (PcUFB2).

\begin{tabular}{cccccc}
\hline Step & $\begin{array}{c}\text { Total Activity } \\
(\mathbf{U} / \mathbf{m L})\end{array}$ & $\begin{array}{c}\text { Total Protein } \\
(\mathbf{m} / \mathbf{m L})\end{array}$ & $\begin{array}{c}\text { Specific Activity } \\
\mathbf{( U / m g )}\end{array}$ & Yield (\%) & $\begin{array}{c}\text { Purification } \\
\text { Fold }\end{array}$ \\
\hline Crude & 10.34 & 4.64 & 2.23 & 100 & 1 \\
Anion Exchange Chromatography & 5.16 & 1.75 & 2.91 & 57.7 & 1.3 \\
Gel Filtration Chromatography & 2.02 & 0.59 & 3.42 & 13.02 & 1.5 \\
\hline
\end{tabular}




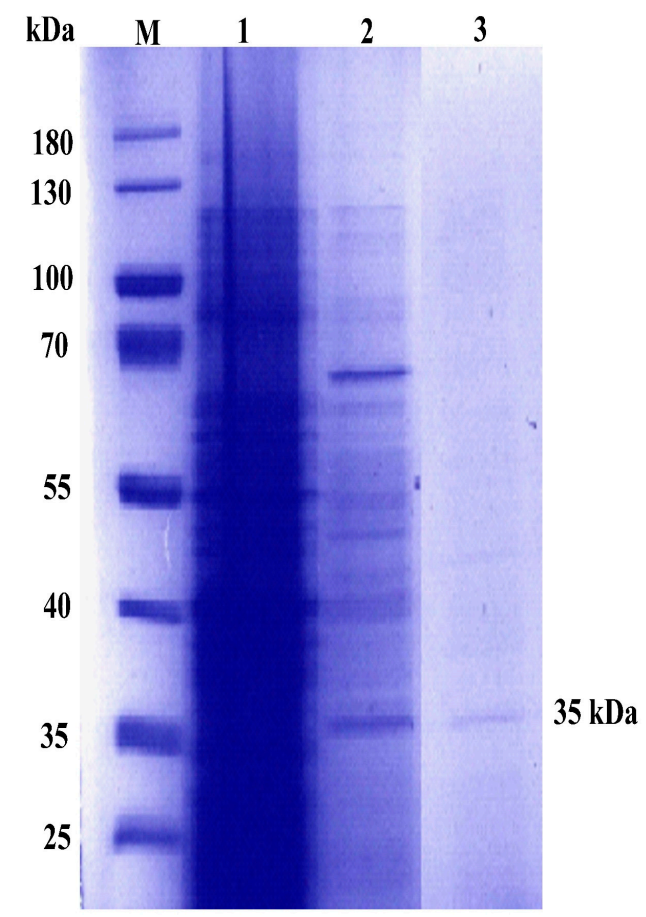

Figure 1. The $12 \%$ SDS-PAGE for crude and purified $\mathrm{C} 12 \mathrm{O}$ from $P_{c} \mathrm{UFB} 2$. Lane $\mathrm{M}=$ protein Marker, Lane 1 = crude cell extract; Lane 2 = anion exchange fractions; Lane 3 = purified $\mathrm{C} 12 \mathrm{O}$ from gel filtration fractions showing a band at $35 \mathrm{kDa}$.

\subsection{Optimum $\mathrm{pH}$ and $\mathrm{pH}$ Stability of Purified $\mathrm{C} 12 \mathrm{O}$}

Purified $\mathrm{C} 12 \mathrm{O}$ showed optimum activity at $\mathrm{pH} 7.5$ (Figure $2 \mathrm{~A}$ ), retaining $84 \%$ and $80 \%$ of its activity at $\mathrm{pH} 7$ and 8, respectively. Incubation of the enzyme for a period of $240 \mathrm{~min}$ and assayed at its optimum conditions showed that the enzyme was stable until $240 \mathrm{~min}$ at $\mathrm{pH} 8$, retaining $79 \%$ activity. At $\mathrm{pH} 4$, the enzyme lost about 50\% activity after $180 \mathrm{~min}$ and $90 \%$ activity after $240 \mathrm{~min}$. At $\mathrm{pH} 6$, the enzyme retained $63 \%$ of its activity after $180 \mathrm{~min}$ and lost about $64 \%$ activity in $240 \mathrm{~min}$. The enzyme was quite stable at $\mathrm{pH} 7$, retaining $86 \%$ activity after $150 \mathrm{~min}$ and about $60 \%$ after $240 \mathrm{~min}$ (Figure 2B).

A

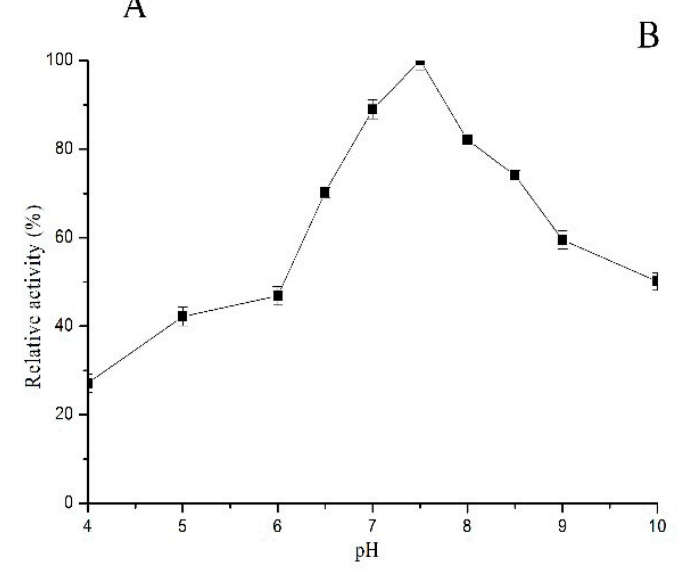

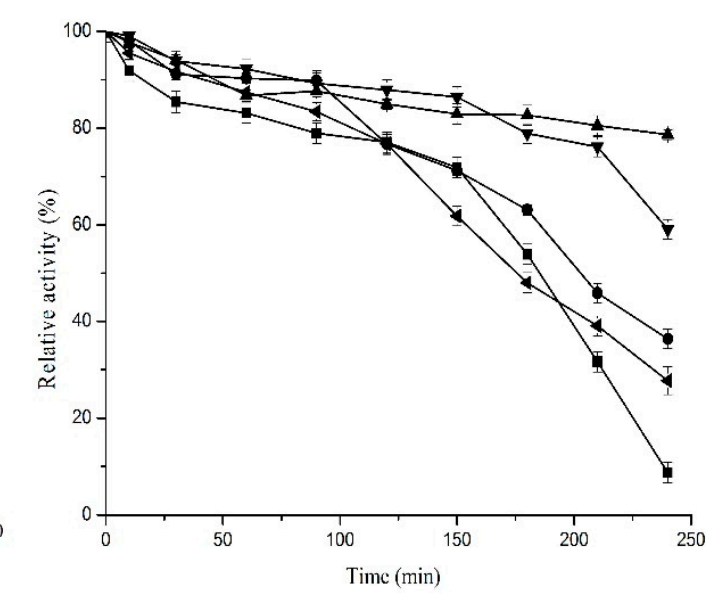

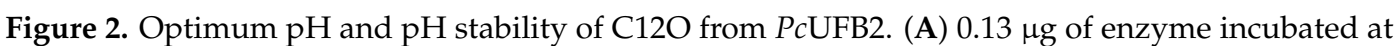
different $\mathrm{pH}$ and assayed for enzyme activity; (B) $\mathrm{pH}$ stability profile of $\mathrm{C} 12 \mathrm{O}$ at $\mathrm{pH} 4(\mathbf{\square}), \mathrm{pH} 6(\bullet)$, pH 7( $\mathbf{\nabla})$, pH 8 (४), and pH 10 (४). 


\subsection{Optimum Temperature and Temperature Stability}

Purified $\mathrm{C} 12 \mathrm{O}$ showed an optimum activity at $30{ }^{\circ} \mathrm{C}$ (Figure $3 \mathrm{~A}$ ), with $81 \%$ and $82 \%$ of its activity retained at $25^{\circ} \mathrm{C}$ and $35^{\circ} \mathrm{C}$, respectively. The enzyme was stable until $120 \mathrm{~min}$ at $30^{\circ} \mathrm{C}$ and lost only $5 \%$ activity even after incubation at $240 \mathrm{~min}$. $\mathrm{C} 12 \mathrm{O}$ was found to be unstable at $70{ }^{\circ} \mathrm{C}$ with $60 \%$ activity loss within $125 \mathrm{~min}$ and about $90 \%$ activity loss after $240 \mathrm{~min}$. At $50{ }^{\circ} \mathrm{C}$ there was $50 \%$ loss of activity after $100 \mathrm{~min}$, and the activity drastically decreased after $240 \mathrm{~min}$ with only $10 \%$ of activity remaining (Figure 3B).

A

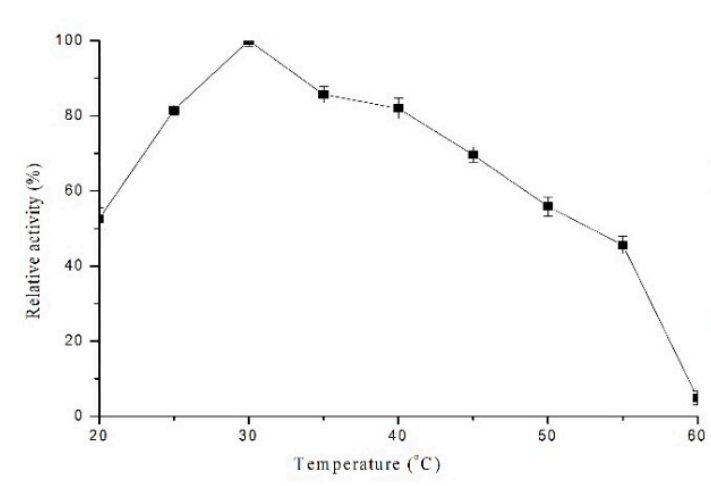

B

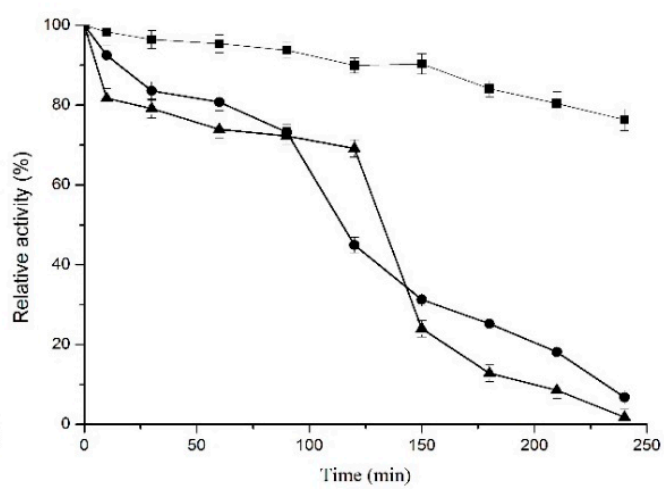

Figure 3. Optimum temperature and temperature stability of $\mathrm{C} 12 \mathrm{O}$ from PcUFB2. (A) $0.13 \mu \mathrm{g}$ of enzyme incubated at a different temperatures and the activity was measured at optimum $\mathrm{pH}$ (7.5);

(B) The temperature stability of $\mathrm{C} 12 \mathrm{O}$ at $30^{\circ} \mathrm{C}(\mathbf{\square}), 50^{\circ} \mathrm{C}(\bullet)$, and $70^{\circ} \mathrm{C}(\mathbf{\Delta})$.

\subsection{The Kinetic Properties of $\mathrm{C} 12 \mathrm{O}$}

The Lineweaver-Burk plots fitted in the Michaelis-Menten equation showed the $K_{\mathrm{m}}$ and $v_{\max }$ values of $35.76 \mu \mathrm{M}$ and $16.67 \mu \mathrm{M} / \mathrm{min}$, respectively (Supplementary Material Figure S3). The enzyme $(0.13 \mu \mathrm{g})$ became saturated with $200 \mu \mathrm{M}$ of catechol, showing the maximum reaction velocity constant until $500 \mu \mathrm{M}$ of catechol. The curve did not indicate any type of substrate inhibition of the enzyme.

\subsection{Effects of Metals and Inhibitors on $\mathrm{C} 12 \mathrm{O}$ Activity}

The effects of metals and inhibitors on purified $\mathrm{C} 12 \mathrm{O}$ activity were evaluated by incubating 100 microliters $(0.13 \mu \mathrm{g})$ of enzyme with a specific concentration of metals and inhibitors. In the presence of $\beta$-mercaptoethanol and EDTA, the enzyme showed $59 \%$ and $58 \%$ residual activity, respectively. $\mathrm{C} 12 \mathrm{O}$ activity was drastically inhibited in the presence of metal ions like $\mathrm{Cu}^{2+}$, and $\mathrm{Hg}^{2+}$ with residual activity of $33 \%$ and $15 \%$, respectively. The surfactants: Tween 20 and Tween 80 reduced the activity by only $20 \%$ and $4 \%$, respectively. The protein denaturing agent SDS reduced activity to $10 \%$, almost deactivating the enzyme (Table 2 ).

Table 2. Effects of metals and inhibitors $(1 \mathrm{mM})$ on the purified $\mathrm{C} 12 \mathrm{O}$ from PcUFB2.

\begin{tabular}{cc}
\hline Metal/Inhibitor/Detergent & Residual Activity (\%) * \\
\hline None (Control) & $100.00 \pm 0.04$ \\
$\beta$-Mercaptoethanol & $59.00 \pm 0.03$ \\
EDTA & $58.00 \pm 0.02$ \\
$\mathrm{CuSO}_{4}$ & $33.00 \pm 0.01$ \\
$\mathrm{HgCl}_{2}$ & $15.00 \pm 0.02$ \\
Tween $20^{\text {Tween } 80}$ & $80.00 \pm 0.02$ \\
SDS & $96.00 \pm 0.02$ \\
\hline
\end{tabular}

* Residual activity of $\mathrm{C} 12 \mathrm{O}$ represented the percentage of activity $(\mathrm{U} / \mathrm{mL})$ in the presence of various substrates (metals and inhibitors) as compared to the activity measured in the presence of catechol. 


\subsection{Substrate Specificity of $\mathrm{C} 12 \mathrm{O}$}

$\mathrm{C} 12 \mathrm{O}$ showed more affinity to catechol as compared to other substrates (Table 3). The enzyme could catalyze phenol efficiently, showing $72 \%$ of residual activity as compared to catechol. C12O showed only $25 \%, 21 \%$, and $51 \%$ of residual activity in the presence of 4-nitrophenol, 1,2,4-benzenetriol, and 2,4-DCP, respectively. C12O did not show any activity in the presence of 3-methylcatechol and 4-methylcatechol. The specific homogentisate 1,2-dioxygenase (H12D) activity was found to be $60 \mathrm{nmol}^{-1} \cdot \mathrm{min}^{-1} \cdot \mathrm{mg}^{-1}$. The H12D activity could not be compared with other substrates as the products measured are different.

Table 3. Substrate specificity of purified C12O from PcUFB2.

\begin{tabular}{cc}
\hline Substrates & Residual Activity (\%) ${ }^{*}$ \\
\hline Catechol & $100.00 \pm 0.01$ \\
4-Nitrocatechol & $25.00 \pm 0.00$ \\
4-Methylcatechol & $0.00 \pm 0.00$ \\
3-Methylcatechol & $0.00 \pm 0.00$ \\
1,2,4-Benzenetriol & $21.00 \pm 0.02$ \\
Phenol & $72.00 \pm 0.02$ \\
2,4-Dichlorophenol & $51.00 \pm 0.00$ \\
Homogentisate & $60 \mathrm{nmol}^{-1} \cdot \mathrm{min}^{-1} \cdot \mathrm{mg}^{-1 \#}$ \\
\hline
\end{tabular}

* Residual activity of $\mathrm{C} 12 \mathrm{O}$ represented as the percentage of $\mathrm{U} / \mathrm{mL}$ activity in the in the presence of various substrates as compared to the activity measured in the presence of catechol. \# cannot be calculated relatively as the products measured are different.

\subsection{Amplification and Detection of $\mathrm{C} 12 \mathrm{O}$ in PcUFB2}

To confirm the presence of the $\mathrm{C} 12 \mathrm{O}$ gene in PcUFB2, primers were designed, and PCR experiments were performed. The results showed the amplification of the expected amplicon size of $467 \mathrm{bp}$ as visualized on 1\% agarose gel (Supplementary Material Figure S4).

\subsection{ES-MS and Amino Acid Sequence Determination}

The pure protein band from SDS-PAGE digested with trypsin generated six spectra matched with the gentisate oxidizing enzyme H12D (accession number: A0A0G3GN46, UniProt). H12D is involved in the catabolism of homogentisate (2,5-dihydroxyphenylacetate), a central intermediate in the degradation of phenylalanine and tyrosine. It catalyzes the oxidative ring cleavage of the aromatic ring of homogentisate to yield maleylacetoacetate. Pseudomonas chlororaphis accession number A0A0G3GN46 searched on www.Uniprot.org led to the depiction of an amino acid sequence of H12D. The protein featured an RmlC-like cupin domain superfamily (IPR011051). RmlC is a dimer, with each monomer formed from two beta-sheets arranged in a beta-sandwich, where the substrate-binding site is located between the two sheets of both monomers (http:/ /www.ebi.ac.uk/interpro/entry/IPR011051).

\subsection{Template-Based Structure of Homogentisate 1,2-Dioxygenase}

The amino acid sequence of H12D was retrieved from UniProt (A0A0G3GN46) and submitted at SWISS-MODEL. The predicted Model 3zds.1.A showed 81.06\% homology with H12D from Pseudomonas chlororaphis (Figure 4A,B). The active site of H12D comprises the residues His292, His335, His365, His371, and Glu341. The active sites residues Glu341, His335, and His371 bind to homogentisate via the $\mathrm{Fe}^{2+}$ atom. His292 binds the hydroxyl group of the aromatic ring, and His365 binds to Glu341 via hydrogen bonding for amino acid stability [19]. 


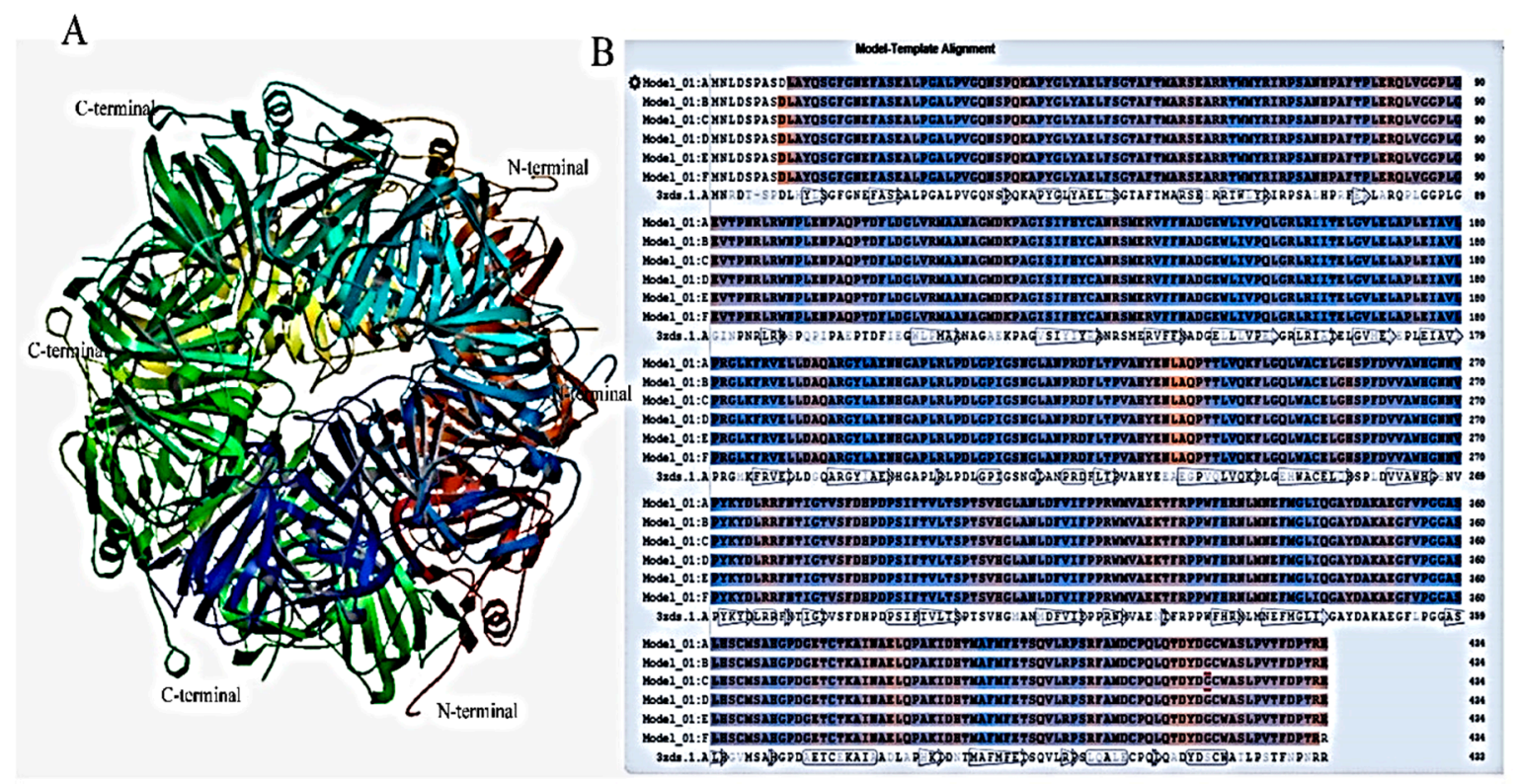

Figure 4. The model constructed by homology modeling at a SWISS-MODEL workspace using homogentisate 1,2-dioxygenase (H12D) from Pseudomonas chlororaphis as the template. (A) The predicted tertiary structure of H12D from PcUFB2 deduced from 3zds.1.A; (B) Homology alignment of probable H12D from PcUFB2 (Model_1) with H12D from Pseudomonas chlororaphis (3zds.1.A).

\subsection{Predicted Biophysical Properties of $\mathrm{C} 12 \mathrm{O}$}

The biophysical parameters of the enzyme were determined by using the ExPaSy server. The parameters on the ExPaSy server included the number of amino acids, molecular weight, theoretical $\mathrm{pI}$ (isoelectric point, the $\mathrm{pH}$ at which a protein has no net charge), extinction coefficients $\left(\mathrm{M}^{-1} \mathrm{~cm}^{-1}\right)$, estimated half-life, instability index (II), aliphatic index (AI) and grand average of hydropathicity (GRAVY). There were 314 amino acids present in $\mathrm{C} 12 \mathrm{O}$ from $P c \mathrm{UFB} 2$, with predicted molecular weight of $34.58 \mathrm{kDa}$ and $\mathrm{pI}$ of 5.18 , showing that $\mathrm{C} 12 \mathrm{O}$ is acidic in nature. The extinction coefficient of the enzyme was found to be $30,035 \mathrm{M}^{-1} \mathrm{~cm}^{-1}$. The estimated half-life of $\mathrm{C} 12 \mathrm{O}$ in E. coli in vitro was calculated to be greater than $10 \mathrm{~h}$, showing its stability in prokaryotic cells. The instability index of the enzyme (39.92) showed that $\mathrm{C} 12 \mathrm{O}$ was stable in vitro. The aliphatic index above 70 indicated that $\mathrm{C} 12 \mathrm{O}$ is thermostable. $\mathrm{C} 12 \mathrm{O}$ showed negative GRAVY $(-0.477)$ indicating that the enzyme is hydrophilic.

\section{Discussion}

In this study, catechol 1,2-dioxygenase (C12O) from Pseudomonas chlororaphis strain UFB2 (PcUFB2) was purified to 1.5 -fold with a $13.02 \%$ yield. $\mathrm{C} 12 \mathrm{O}$ showed a molecular weight of $35 \mathrm{kDa}$. PCR experiments also confirmed the presence of the $\mathrm{C} 12 \mathrm{O}$ gene in $\mathrm{PcUFB} 2$. Other studies have shown that C12Os from Pseudomonas spp. include homodimers and homo-tetramers and fall in the molecular weight range $20-40 \mathrm{kDa}[15,20]$. In this study, the optimum $\mathrm{pH}$ and temperature of $\mathrm{C} 12 \mathrm{O}$ were found to be $\mathrm{pH} 7.5$ and $30^{\circ} \mathrm{C}$, respectively. $\mathrm{C} 12 \mathrm{O}$ from Rhodococcus sp. NCIM 2891 also showed optimum activity at $\mathrm{pH} 7.5$ and $30^{\circ} \mathrm{C}$ [21]. C12Os from other microorganisms have been shown to be optimum at different conditions. For example, the optimum activity for $\mathrm{C} 12 \mathrm{O}$ was recorded at $\mathrm{pH} 8$ and $37^{\circ} \mathrm{C}$ for Acinetobacter sp. Y64 strain [22]; pH 7 and $30^{\circ} \mathrm{C}$ for Gordonia polyisoprenivorans [11]; and pH 7.5 and $35^{\circ} \mathrm{C}$ for Pseudomonas putida strain N6 [23]. However, an optimum temperature of $40{ }^{\circ} \mathrm{C}$ has been reported for $\mathrm{C} 12 \mathrm{O}$ in Pseudomonas aeruginosa KB2 and Candida albicans TL3 strains [14,24]. C12O from Mycobacterium fortuitum immobilized on different surfaces have been reported to have an elevated optimum temperature of $45^{\circ} \mathrm{C}$. 
The Lineweaver-Burk plot showed the $K_{\mathrm{m}}$ and $v_{\max }$ values of $35.76 \mu \mathrm{M}$ and $16.67 \mu \mathrm{M} / \mathrm{min}$, respectively. The $v_{\max }$ for $\mathrm{C} 12 \mathrm{O}$ was about 105 -fold higher than the previously reported $v_{\max }$ of $1218.8 \mathrm{U} / \mathrm{mg}$ for $\mathrm{C} 12 \mathrm{O}$ from Stenotrophomonas maltophilia $\mathrm{KB} 2$ [25]. The $v_{\max }$ for $\mathrm{C} 12 \mathrm{O}$ from Rhodococcus opacus 1CP and Rhodococcus opacus 6a were found to be $9.6 \mu \mathrm{M} / \mathrm{min}$ and $55.5 \mu \mathrm{M} / \mathrm{min}$, respectively [26]. The $K_{\mathrm{m}}$ value in this study was higher than previously reported $[21,24,25]$, indicating that the enzyme has less affinity for catechol.

Investigation of the effect of metal ions and detergent on $\mathrm{C} 12 \mathrm{O}$ revealed that the enzyme activity was significantly inhibited by heavy metals like $\mathrm{Cu}^{2+}$ and $\mathrm{Hg}^{2+}$ and the denaturing agent SDS. However, EDTA, Tween 20, Tween 80, and $\beta$-mercaptoethanol also showed $42 \%, 20 \%, 4 \%$, and $41 \%$ inhibitory activity, respectively. Similar results were reported for a $\mathrm{C} 12 \mathrm{O}$ from Rhodococcus sp. NCIM 2891, which was also inhibited by $\mathrm{Cu}^{2+}$ and $\mathrm{Hg}^{2+}$ [21]. However, a different trend in the effect of inhibitors and metals on $\mathrm{C} 12 \mathrm{O}$ from Candida albicans $\mathrm{TL} 3$ was reported, where $\mathrm{CuSO}_{4}$ was found to not affect the activity of the enzyme [14], contrary to the observation in the current study.

$\mathrm{C} 12 \mathrm{O}$ elucidated a wide range of substrate specificity, showing high affinity for catechol and homogentisate. $\mathrm{C} 12 \mathrm{O}$ showed low affinity for 2,4-dichlorophenol, 1,2,4-benzenetriol, 4-nitrocatechol, and phenol relative to catechol. Studies have reported that $\mathrm{C} 12 \mathrm{O}$ s from different microorganisms have different substrate specificity. $\mathrm{C} 12 \mathrm{O}$ from Stenotrophomonas maltophilia $\mathrm{KB} 2$ catalyzed 3-methylcatechol and 4-methylcatechol with 50\% less efficiency as compared to catechol, while 2,4-dichlorophenol showed $74 \%$ relative activity [25]. C12O from PcUFB2 was induced more efficiently when catechol was used as a substrate. Similar findings were reported where $\mathrm{C} 12 \mathrm{O}$ from Acinetobacter sp. DS002 was induced by catechol, 1,2,4-benzenetriol, and 4-nitrocatechol, while 3-methylcatechol and 4-methylcatechol could not induce the expression of the enzyme [27]. In another study, 3 -methylcatechol resulted in the induction of very low activity in Acinetobacter sp. Y $64(2 \%$ as compared to catechol), 1,2,4-benzenetriol, and 4-nitrocatechol, but 4-methylcatechol was able to induce high enzyme activity ( $80 \%$ as compared to catechol) [22]. In Aspergillus awamori, 2,4-dichlorophenol could not induce $\mathrm{C} 12 \mathrm{O}$ [28]. Studies have shown that $\mathrm{C} 12 \mathrm{O}$ expressed in Rhodococcus, Ralstonia, and Pseudomonas arvilla has a broad substrate specificity $[27,29]$.

The purified protein band digested with trypsin and followed by ES-MS analysis resulted in the depiction of the amino acid sequence. The results showed that $\mathrm{C} 12 \mathrm{O}$ activity may be due to homogentisate 1,2-dioxygenase (H12D) expressed in PcUFB2. The amino acid sequence of H12D showed $81.06 \%$ homology with model 3zds.1.A on SWISSPROT, which could lead to its structure prediction. It was also confirmed that H12D is an intradiol enzyme and catalyzes homogentisate to maleylacetoacetate. It has been reported that the ring cleavage in homogentisate is a multiple-step process. The initial step is the coordination of carbonyl and ortho phenol oxygens by $\mathrm{Fe}^{2+}$ to His335, His371, and Glu341 [25]. The structure shows an octahedral coordination for $\mathrm{Fe}^{2+}$ with two histidine residues (His331 and His367), a bidentate carboxylate ligand (Glu337), and two water molecules. Homogentisate binds as a monodentate ligand to $\mathrm{Fe}^{2+}$, and its interaction with Tyr346 results in the folding of a loop over the active site, effectively shielding it from solvent [30]. In Pseudomonas putida, homogentisate cleavage is facilitated by H12D, producing maleylacetoacetate. The maleylacetoacetate is isomerized to fumarylacetoacetate by maleylacetoacetate isomerase. Fumarate and acetoacetate are then formed from the catalysis of fumarylacetoacetate by fumarylacetoacetate hydrolase [31]. Oxygen atom $\left(\mathrm{O}_{2}\right)$ binds to the iron atom and reacts with the aromatic ring [25,31]. Most intradiol dioxygenases enzymes have an $\mathrm{N}$-terminal domain with five $\alpha$-helices and a C-terminal domain consisting of $\beta$-sheets. A similar structure of $\mathrm{C} 12 \mathrm{O}$ from Pseudomonas putida $\mathrm{N} 6$ has been reported [23]. It is probable that in PcUFB2, catechol oxidation is facilitated by H12D, leading to the production of maleylacetoacetate. To the best of our knowledge, this is the first report of H12D oxidizing catechol and other related substrates (Table 3).

The biophysical properties reported in this study were found to be like those previously reported for $\mathrm{C} 12 \mathrm{O}$ from Pseudomonas spp., where molecular weight ranged from 22 to $40 \mathrm{kDa}$ and $\mathrm{pI}$ ranged from 4 to 8 [15]. The instability index differed and ranged from to 35 to 47 , which indicates that the 
enzyme can be stable or unstable depending on its type and location. The aliphatic index ranging from 70 to 85 showed that the enzyme can be thermostable and hydrophilic, showing a negative GRAVY value. The bioinformatics and biophysical study of $\mathrm{C} 12 \mathrm{O}$ in other Pseudomonas spp. showed that the number of amino acids, molecular weight, and pI had the ranges 314-327, 34-36, and 4-11 kDa, respectively. Almost all the $\mathrm{C} 12 \mathrm{O}$ reported in Pseudomonas spp. are found to be acidic in nature, except from Pseudomonas chlororaphis strain PCL1606 showing pI 11.37, and basic in nature. The estimated half-life for all $\mathrm{C} 12 \mathrm{O}$ ( $E$. coli in vitro) was greater than $10 \mathrm{~h}$. The aliphatic index of the enzyme ranged from 52 to 79, with the lowest value of 52.57 obtained for Pseudomonas chlororaphis strain PCL1606.

\section{Materials and Methods}

\subsection{Sample Collection, Enrichment, and Isolation of Bacterial Isolates}

Sample collection, media preparation, enrichment and isolation of cultures were performed as described previously with some modifications [32]. An activated sludge sample with known history of contamination with chlorinated organic compounds was collected from the New Germany wastewater treatment plant located in Durban, South Africa. Samples were collected in $500 \mathrm{~mL}$ bottles and immediately stored at $4{ }^{\circ} \mathrm{C}$ until used for the culture enrichment set-up. The mineral salt medium (MSM) used for the culture enrichment comprised (in mg/L): $\mathrm{KH}_{2} \mathrm{PO} 4,800 ; \mathrm{Na}_{2} \mathrm{HPO}_{4}, 800$; $\mathrm{MgSO}_{4} \cdot 7 \mathrm{H}_{2} \mathrm{O}, 200 ; \mathrm{NH}_{4} \mathrm{SO}_{2}, 500$. The $\mathrm{pH}$ was adjusted to 7.5 using $2 \mathrm{M} \mathrm{NaOH}$ prior to autoclaving at $121{ }^{\circ} \mathrm{C}$ for $15 \mathrm{~min}$. One $\mathrm{mL}$ of trace metal which comprised (in mg/L): $\mathrm{FeSO}_{4} \cdot 7 \mathrm{H}_{2} \mathrm{O}, 5 ; \mathrm{ZnSO}_{4} \cdot 7 \mathrm{H}_{2} \mathrm{O}$, 4; $\mathrm{MnSO}_{4} \cdot 4 \mathrm{H}_{2} \mathrm{O}, 0.2 ; \mathrm{NiCl} \cdot 6 \mathrm{H}_{2} \mathrm{O}, 0.1 ; \mathrm{H}_{3} \mathrm{BO}_{3}, 0.15 ; \mathrm{CoCl}_{2} \cdot 6 \mathrm{H}_{2} \mathrm{O}, 0.5 ; \mathrm{ZnCl}_{2}, 0.25$; EDTA, 2.5 was added by syringe filter $(0.2 \mu \mathrm{m}$ pore $)$ into $1 \mathrm{~L}$ MSM. Ten percent of the activated sludge sample was inoculated into MSM that was supplemented with $40 \mathrm{ppm}$ of 2,4-dicholorophenol (2,4-DCP) in a $250 \mathrm{~mL}$ Erlenmeyer flask and incubated at $30^{\circ} \mathrm{C}$ and shaken at $150 \mathrm{rpm}$ for a week. Sub-culturing in fresh MSM was carried out until a stable and consistent culture was obtained. Aliquots from each culture were spread on MSM agar plates supplemented with $40 \mathrm{ppm}$ of 2,4-DCP and incubated at $30^{\circ} \mathrm{C}$ until visible growth of the microorganisms was observed. Pure cultures were obtained by streaking individual morphologically different colonies on nutrient agar plates. The pure colonies were stored at $-70{ }^{\circ} \mathrm{C}$ as $20 \%(v / v)$ glycerol stocks.

\subsection{Identification and Phylogenetic Analysis of the Bacterial Isolate}

The $16 \mathrm{~S}$ rRNA gene was amplified from the purified genomic DNA (Genomic DNA Purification Kit, Thermo Scientific, Waltham, MA, USA) of the bacterial isolate as a template using the universal primer pair: 63F-5'-CAGGCCTAACACATGCAAGTC- $3^{\prime}$ and 1387R-5'-GGGCGGTGTGTACAAGGC-3' [33]. Ten microliters of PCR reaction mixture contained: $1 \mu \mathrm{L}$ buffer $(10 \times), 0.6 \mu \mathrm{L} \mathrm{MgCl}{ }_{2}$ of $(25 \mathrm{mM}), 0.2 \mu \mathrm{L}$ of $200 \mu \mathrm{M}$ dNTPs, $0.2 \mu \mathrm{L}$ of each primer $(10 \mu \mathrm{m})$, $0.05 \mu \mathrm{L}$ of AmpliTaq polymerase, $\sim 20 \mathrm{ng}$ DNA template, and $7.3 \mu \mathrm{L}$ autoclaved double distilled water. The PCR conditions were as follows: $95{ }^{\circ} \mathrm{C}$ for $5 \mathrm{~min}$, ( 1 cycle) $95^{\circ} \mathrm{C}$ for $30 \mathrm{~s}, 55^{\circ} \mathrm{C}$ for $1 \mathrm{~min}$, and $72{ }^{\circ} \mathrm{C}$ for $1 \mathrm{~min}$ ( 35 cycles), and a final elongation at $72{ }^{\circ} \mathrm{C}$ for $10 \mathrm{~min}$ (1 cycle). The amplified $16 \mathrm{~S}$ rRNA gene was sequenced at Inqaba Biotechnical Industries (Pretoria, South Africa) and submitted to the National Centre for Biotechnology Information (NCBI) database (http:/ / www.ncbi.nlm.nih.gov/blast/ using the blastn algorithm) for the identification of organisms. The $16 \mathrm{~S}$ rRNA gene sequences were retrieved from NCBI and the phylogenetic tree was constructed by a rooted neighbor-joining method using DNAMAN (Lynnon Corporation, CA, USA; v.7 Demo version). The numbers on branching points are bootstrap values with 1000 replicates (values $<95 \%$ were not included) (Supplementary Material Figure S5). 


\subsection{Preparation of Crude Extracts for Catechol 1,2-Dioxygenase (C12O) and Catechol 2,3-Dioxygenase (C23O) Activity}

The crude extract was prepared by growing the bacterial cells for $36 \mathrm{~h}$ in mineral salt medium (MSM) comprising (g/L): $\mathrm{K}_{2} \mathrm{HPO}_{4}, 2.75 ; \mathrm{KH}_{2} \mathrm{PO}_{4}, 0.1 ; \mathrm{NH}_{4} \mathrm{Cl}, 0.2 ; \mathrm{MgSO}_{4} \cdot 7 \mathrm{H}{ }_{2} \mathrm{O}, 0.01 ; \mathrm{CaCl}_{2} \cdot 2 \mathrm{H}_{2} \mathrm{O}$, 1.0; $\mathrm{NH}_{4} \mathrm{Cl}, 0.5$, and yeast extract, 1.0. The $\mathrm{pH}$ was adjusted to 7.0 with $2 \mathrm{M} \mathrm{NaOH}$ prior to autoclaving at $121{ }^{\circ} \mathrm{C}$ for $15 \mathrm{~min}$. One milliliter of trace metal solution composed of $(\mathrm{mg} / \mathrm{L})$ : $\mathrm{FeSO}_{4} \cdot 7 \mathrm{H}_{2} \mathrm{O}, 5$; $\mathrm{ZnSO}_{4} \cdot 7 \mathrm{H}_{2} \mathrm{O}, 4 ; \mathrm{MnSO}_{4} \cdot 4 \mathrm{H}_{2} \mathrm{O}, 0.2 ; \mathrm{NiCl} \cdot 6 \mathrm{H}_{2} \mathrm{O}, 0.1 ; \mathrm{H}_{3} \mathrm{BO}_{3}, 0.15 ; \mathrm{CoCl}_{2} \cdot 6 \mathrm{H}_{2} \mathrm{O}, 0.5 ; \mathrm{ZnCl}_{2}, 0.25 ;$ EDTA, 2 was added by syringe filter $(0.2 \mu \mathrm{L}$ pore) into $1 \mathrm{~L}$ of the MSM. PcUFB2 cells were grown in nutrient broth overnight at $30^{\circ} \mathrm{C}$ and the culture was standardized to $\mathrm{OD}=1$ at $600 \mathrm{~nm}$. Ten percent of the standardized culture was inoculated into the above-described MSM supplemented with $600 \mathrm{ppm}$ of phenol as a sole carbon and energy source. The inoculated medium was incubated at $30^{\circ} \mathrm{C}$ for $36 \mathrm{~h}$, shaking at $150 \mathrm{rpm}$. The cells were harvested at the late exponential phase of growth by centrifugation at $10,000 \times \mathrm{g}$ for $15 \mathrm{~min}$ at $4{ }^{\circ} \mathrm{C}$. The cells were washed twice with $50 \mathrm{mM}$ sodium phosphate buffer, $\mathrm{pH} 7.5$ (containing $1 \mathrm{mM}$ EDTA and $1 \mathrm{mM} \beta$-mercaptoethanol to halt the protease activity). A total of $24 \mathrm{~g}$ of the cell pellet was collected and re-suspended in $100 \mathrm{~mL}$ of the same buffer. Cell-free extracts were prepared by lysing the pellet by sonication with a 400 Ultrasonicator (OMNI International), 8 cycles each with a pulse of $30 \mathrm{~s}$ on/off for $4 \mathrm{~min}$. The cell extract was centrifuged at 20,000 $\times g$ for $30 \mathrm{~min}$ at $4{ }^{\circ} \mathrm{C}$. The clear supernatant was kept on ice to prevent inactivation of the enzymes and used as a crude extract for enzyme assays, while the remaining extract was kept in $-20^{\circ} \mathrm{C}$ for further studies [4].

\section{4. $\mathrm{C} 12 \mathrm{O}$ and $\mathrm{C} 23 \mathrm{O}$ Activity Assay}

$\mathrm{C} 12 \mathrm{O}$ and $\mathrm{C} 23 \mathrm{O}$ activity were assayed in a $1 \mathrm{~mL}$ reaction mixture as described previously $[4,32]$. The reaction mixture contained $10 \mathrm{mM}$ of catechol in $50 \mathrm{mM}$ sodium phosphate buffer ( $\mathrm{pH} 8.0$ ). The reaction was initiated by adding $100 \mu \mathrm{L}$ of crude enzyme into the reaction mixture and incubated for $30 \mathrm{~min}$ at $30^{\circ} \mathrm{C}$. Buffer plus the enzyme only, and buffer plus substrate without the enzyme were used as controls. The initial and final absorbance at 260 and $375 \mathrm{~nm}$ were measured using a UV-Vis spectrophotometer (UV-1800, Shimadzu, Kyoto, Japan) fitted with a CPS-240A temperature controller unit set at $30{ }^{\circ} \mathrm{C}$. One unit of enzyme activity was defined as the amount of the enzyme that produced $1 \mu \mathrm{M}$ of either cis,cis-muconic acid at $260 \mathrm{~nm}$ (catechol 1,2-dioxygenase) or 2-hydroxymuconic semialdehyde at $375 \mathrm{~nm}$ (catechol 2,3-dioxygenase) under standard assay conditions. Enzyme activity was calculated using the equation: enzyme activity ( $\mu \mathrm{m}$ of product formed $/ \mathrm{min})=\{(\varepsilon \times L / V)$ $(\Delta \mathrm{OD} / \mathrm{min})\}$, where $\Delta \mathrm{OD}$ is the change in optical density at the different wavelengths; $\varepsilon$ is the molar extinction coefficient of the product; " $V$ " is the reaction volume, and " $L$ " is the path length (mm). The molar extinction coefficients $16,800 \mathrm{mM}^{-1} \cdot \mathrm{cm}^{-1}$ (muconic acid) and $14,700 \mathrm{mM}^{-1} \cdot \mathrm{cm}^{-1}$ (2-hydroxysemialdehyde) were used to determine the activities for catechol 1,2-dioxygenase and catechol 2,3-dioxygenase, respectively [4,32].

\subsection{Purification of $\mathrm{C} 12 \mathrm{O}$}

The enzyme was purified by using anion exchange and gel filtration chromatography. For anion exchange, $1 \mathrm{~mL}$ anion exchange HiTrap ANX column was equilibrated with five column volumes $(\mathrm{CVs})(1 \mathrm{CV}=5 \mathrm{~mL})$ of $20 \mathrm{mM}$ sodium sulfate buffer $(\mathrm{pH}$ 8) and $1 \mathrm{~mL}(200 \mu \mathrm{g}$ total protein) of the sample was loaded into the column. The unbound proteins were washed with $5 \mathrm{CV}$ of $20 \mathrm{mM}$ sodium sulfate buffer ( $\mathrm{pH}$ 8). The proteins bound to the matrix were eluted with $10 \mathrm{CV}$ of a 0-1.0 M linear gradient of $\mathrm{NaCl}$ in $20 \mathrm{mM}$ sodium sulfate buffer ( $\mathrm{pH}$ 8). The eluted proteins were collected as $1 \mathrm{~mL}$ fractions using the AKTA purifier 100-P950 automated fraction collector at a flow rate of $1 \mathrm{~mL} / \mathrm{min}$. The fractions showing $\mathrm{C} 12 \mathrm{O}$ activity were concentrated with chilled acetone (200 $\mu \mathrm{L}$ of fractions and $800 \mu \mathrm{L}$ acetone) for $2 \mathrm{~h}$ at $-70{ }^{\circ} \mathrm{C}$, and the samples were loaded on $12 \%$ SDS-PAGE to confirm purity and homogeneity. The fractions showing the $\mathrm{C} 12 \mathrm{O}$ activity were pulled together and concentrated using an Amicon Ultra-15 centrifugal filter unit (MW cut off $10 \mathrm{kDa})$. One milliliter of sample $(0.36 \mathrm{mg}$ 
of total protein) was again loaded in a $35 \mathrm{~mL}(1 \mathrm{CV})$ gel filtration column manually packed with Sephacryl HR 100 matrix (from Sigma-Aldrich, St Louis, MO, USA) and equilibrated with 2 CV of $20 \mathrm{mM}$ sodium sulfate buffer $(\mathrm{pH}$ 8) and collected as $2 \mathrm{~mL}$ fractions using the AKTA purifier 100-P950 automated fraction collector at a flow rate of $0.5 \mathrm{~mL} / \mathrm{min}$. The fractions showing $\mathrm{C} 12 \mathrm{O}$ activity were pulled together and concentrated using an Amicon Ultra-15 centrifugal filter unit (MW cut off $10 \mathrm{kDa}$ ). The fractions were concentrated with chilled acetone ( $200 \mu \mathrm{L}$ of fractions and $800 \mu \mathrm{L}$ acetone) for $2 \mathrm{~h}$ at $-70{ }^{\circ} \mathrm{C}$ and the samples were loaded on $12 \%$ SDS-PAGE to confirm purity and homogeneity [34].

\subsection{Determination of Optimum $\mathrm{pH}$ and Temperature}

The optimum $\mathrm{pH}$ of purified $\mathrm{C} 12 \mathrm{O}$ was determined by setting up a reaction in different buffers as follows: $50 \mathrm{mM}$ citrate-phosphate buffer ( $\mathrm{pH} 4-6.5$ ), sodium phosphate buffer ( $\mathrm{pH}$ 7.0-8.0), and Tris-phosphate buffer ( $\mathrm{pH}$ 8.5-10) [6]. The optimum temperature was determined by incubating the reaction mixture for $30 \mathrm{~min}$ at $20,25,30,35,40,45,50$, and $60^{\circ} \mathrm{C}$. The reaction was set up as described above.

\subsection{Temperature and $\mathrm{pH}$ Stability of $\mathrm{C} 12 \mathrm{O}$}

To determine the $\mathrm{pH}$ stability of $\mathrm{C} 12 \mathrm{O}$, an adequate volume of the enzyme was incubated in buffers: $50 \mathrm{mM}$ citrate-phosphate buffer ( $\mathrm{pH} 4$ and 6), $50 \mathrm{mM}$ sodium phosphate buffer ( $\mathrm{pH} 7.0$ and 8.0), and $50 \mathrm{mM}$ Tris-phosphate buffer $(\mathrm{pH} 10)$ at a designated time (0-2 h). One hundred microliters $(0.13 \mu \mathrm{g})$ of the enzyme aliquots were withdrawn at different time intervals and the enzyme reaction assay was set up as described above. The relative enzyme activity at different pHs was represented related to the initial activity. To determine the temperature stability, an adequate volume of the enzyme $(0.13 \mu \mathrm{g})$ was incubated at 30,50 , and $70{ }^{\circ} \mathrm{C}$ in sodium phosphate buffer $(\mathrm{pH} 8.0)$ for $0-2 \mathrm{~h}$. One hundred microliters $(0.13 \mu \mathrm{g})$ of the enzyme aliquots were withdrawn at different time intervals and the reactions were set up as described above. The residual enzyme activity at different temperatures was represented relative to the initial activity.

\subsection{Determination of the Enzyme Kinetic Parameters}

The kinetic parameters were determined by measuring the initial rate of enzymatic activity. One hundred microliters $(0.13 \mu \mathrm{g})$ of the enzyme was incubated with sodium phosphate buffer $(\mathrm{pH} 8)$ containing catechol $(0-500 \mu \mathrm{M})$ at $30^{\circ} \mathrm{C}$ for $30 \mathrm{~min}$. The Lineweaver-Burk plot was constructed by plotting the reciprocal of the rate of substrate hydrolysis $(1 / \mathrm{V})$ against the reciprocals of the substrate concentrations $(1 /[\mathrm{S}])$. The $v_{\max }$ and $K_{\mathrm{m}}$ values were determined by fitting the data in Michaelis-Menten equation using ORIGIN 8 pro (Evaluation version).

\subsection{Effects of Metals and Inhibitors on $\mathrm{C} 12 \mathrm{O}$ Activity}

One hundred microliters $(0.13 \mu \mathrm{g})$ of purified $\mathrm{C} 12 \mathrm{O}$ was incubated separately with $0.1 \mathrm{mM}$ of $\beta$-mercaptoethanol, EDTA, $\mathrm{CuSO}_{4}, \mathrm{HgCl}_{2}$, Tween 20, Tween 80, and sodium dodecyl sulfate (SDS), and the enzyme assay was performed as described above.

\subsection{Substrate Specificity of $\mathrm{C} 12 \mathrm{O}$}

To determine the substrate specificity of $\mathrm{C} 12 \mathrm{O}$, stock solutions of various substrates (i.e., phenol, 4-nitrocatechol, 3-methylcatechol, 4-methylcatechol, 1,2,4-benzenetriol, catechol, and 2,4-dichlorophenol) were prepared in $50 \mathrm{mM}$ sodium phosphate buffer $(\mathrm{pH} 8)$, except homogentisate was prepared in $20 \mathrm{mM}$ MES (pH8). One hundred microliters $(0.13 \mu \mathrm{M})$ enzyme was added to the $0.1 \mathrm{mM}$ of the substrates except for catechol $(0.2 \mathrm{mM})$ to initiate the reaction, and the assay was performed as described above. Homogentisate 1,2-dioxygenase (H12D) activity was monitored by spectrophotometric method [35,36]. The assay contained $1 \mathrm{~mL}$ of buffer and $200 \mu \mathrm{M}$ homogentisate, and the production of maleylacetoacetate was monitored at $330 \mathrm{~nm}\left\{\varepsilon=10.1 \mathrm{mM}^{-1} \cdot \mathrm{cm}^{-1}, 20 \mathrm{mM} \mathrm{MES}, 80 \mathrm{mM} \mathrm{NaCl}(\mathrm{L}=0.1), \mathrm{pH} 8,25^{\circ} \mathrm{C}\right\}$. 


\subsection{Determination of Amino Acid Sequences of the Purified C12O}

The pure protein $(50 \mu \mathrm{g})$ was loaded onto $12 \%$ SDS-PAGE and stained with Coomassie blue R250. The protein band was excised carefully and digested with trypsin and fragments were analyzed by electrospray mass spectrometry (at CAF, Stellenbosch University, Stellenbosch, South Africa). The raw files generated by the mass spectrometers were imported into Proteome Discoverer v1.3 (Thermo Scientific, USA) and SearchGUI v. 3.2.18 and processed using the Mascot 1.3. Algorithm (Matrix Science) as well as the Sequest algorithm to get the peptides generated from the enzyme. The database from tryptic digestion was analyzed by PeptideShaker (version 1.16.9) for homology of C12O. The FASTA sequence was then used for the functional features at UniProt (http://www.uniprot.org/).

\subsection{Prediction of Biophysical Properties and Three-Dimensional Structure}

The biophysical properties of the protein were determined using ExPASy server, while structure prediction of the enzymes was carried out using SWISS-MODEL workspace (http:/ / swissmodel. expasy.org). The default parameters used for performing the automated SWISS-MODEL were used as explained previously [34] and elaborated at (http:/ / swissmodel.expasy.org/docs/help) webpage. The modeled PDB files were submitted to online tool RAMPAGE for Ramachandran plot analysis to check the quality and validation of the predicted models [34].

\subsection{Amplification and Detection of $\mathrm{C} 12 \mathrm{O}$ in PcUFB2}

To detect and amplify C12O gene in PcUFB2, the whole gene sequence was retrieved from https:/ / www.ebi.ac.uk/ena/data/view/AKK00187. The sequence was exploited to design forward 5'-ATGGCTAACATTCTCGGCGG-3' and reverse primers 5'-TGGCCGAGTTTGTAACAACGG-3' amplifying a $467 \mathrm{bp}$ region. PCR and conditions were used as described above except for the annealing temperature at $62^{\circ} \mathrm{C}$.

\section{Conclusions}

This study covered the purification, characterization, and three-dimensional structure prediction of catechol 1,2-dioxygenase from PcUFB2. The enzyme was found to be identical to the H12D which hydroxylates homogentisate to maleylacetoacetate. The kinetics parameters of the enzyme show that it has high affinity for catechol and homogentisate. Enzyme purification data, SDS-PAGE, and PCR experiments confirmed the presence of catechol oxidizing enzyme in PcUFB2. To the best of our knowledge, this is the first report of an enzyme showing both $\mathrm{C} 12 \mathrm{O}$ and $\mathrm{H} 12 \mathrm{D}$ activity. The characteristics of the purified $\mathrm{C} 12 \mathrm{O}$ showed that the enzyme may have application in the bioremediation of pollutants.

Supplementary Materials: Supplementary materials can be found at http:/ /www.mdpi.com/1422-0067/20/1/ 61/s1.

Author Contributions: Conceptualization, A.O.O., A.K., and M.P.M.; methodology, B.S. and A.K.; software, B.S. and A.K.; validation, B.S., A.K., and A.O.O.; formal analysis, B.S. and A.K.; investigation, B.S. and A.K.; resources, A.O.O. and M.P.M.; data curation, A.K. and A.O.O.; writing-B.S., A.K., and A.O.O.; writing-review and editing, A.K., M.P.M., and A.O.O.; visualization, A.K.; supervision, A.O.O. and M.P.M; project administration, A.O.O. and M.P.M.; funding acquisition, A.O.O. and M.P.M.

Funding: National Research Foundation, South Africa, Grant No: 94036 and 92803.

Acknowledgments: The post-doctoral research fellowship awarded to Ajit Kumar by the University of KwaZulu-Natal, Durban, South Africa. The authors are grateful for the Master of Science scholarship awarded to Boitumelo Setlhare to carry out this study.

Conflicts of Interest: The authors declare no conflict of interest. 


\section{Abbreviations}

PsUFB2 Pseudomonas chlororaphis strain UFB2

C12O Catechol 1,2-Dioxygenase

C23O Catechol 2,3-Dioxygenase

H12D Homogentisate 1,2-Dioxygenase

\section{References}

1. Igbinosa, E.O.; Odjadjare, E.E.; Chigor, V.N.; Igbinosa, I.H.; Emoghene, A.O.; Ekhaise, F.O.; Igiehon, N.O.; Idemudia, O.G. Toxicological profile of chlorophenols and their derivatives in the environment: The public health perspective. Sci. World J. 2013, 2013, 1-11. [CrossRef] [PubMed]

2. Das, N.; Chandran, P. Microbial degradation of petroleum hydrocarbon contaminants: An overview. Biotechnol. Res. Int. 2011, 2011, 1-13. [CrossRef] [PubMed]

3. Karigar, C.S.; Rao, S.S. Role of microbial enzymes in the bioremediation of pollutants: A review. Enzyme Res. 2011, 2011, 1-11. [CrossRef] [PubMed]

4. Mahiudddin, M.; Fakhruddin, A.N.M.; Al-Mahin, A. Degradation of phenol via meta- cleavage pathway by Pseudomonas fluorescens PU1. ISRN Microbiol. 2012, 2012, 1-6. [CrossRef] [PubMed]

5. Arora, P.K.; Bae, H. Bacterial degradation of chlorophenols and their derivatives. Microb. Cell Fact. 2014, 13, 31. [CrossRef] [PubMed]

6. Long, Y.; Yang, S.; Xie, Z.; Cheng, L. Identification and characterization of phenol hydroxylase from phenol-degrading Candida tropicalis strain JH8. Can. J. Microbiol. 2014, 60, 585-591. [CrossRef] [PubMed]

7. Powlowski, J.; Shingler, V. Genetics and biochemistry of phenol degradation by Pseudomonas sp. CF600. Biodegradation 1994, 5, 219-236. [CrossRef]

8. Harayama, S.; Kok, M.; Neidle, E.L. Functional and evolutionary relationships among diverse oxygenases. Annu. Rev. Microbiol. 1992, 46, 565-601. [CrossRef]

9. Cerniglia, C.E. Microbial metabolism of polycyclic aromatic hydrocarbons. Adv. Appl. Microbiol. 1984, 30, 31-71.

10. Shumkova, E.S.; Solyanikova, I.P.; Plotnikova, E.G.; Golovleva, L.A. Phenol degradation by Rhodococcus opacus strain 1G. Appl. Biochem. Microbiol. 2009, 45, 43-49. [CrossRef]

11. Silva, A.S.; Camargo, F.A.; Andreazza, R.; Jacques, R.J.; Baldoni, D.B.; Bento, F.M. Enzymatic activity of catechol 1,2-dioxygenase and catechol 2,3-dioxygenase produced by Gordonia polyisoprenivorans. Quim. Nova 2012, 35, 1587-1592. [CrossRef]

12. Sridevi, V.; Lakshmi, M.; Manasa, M.; Sravani, M. Metabolic pathways for the biodegradation of phenol. Int. J. Eng. Sci. Adv. Technol. 2012, 2, 695-705.

13. Krastanov, A.; Alexieva, Z.; Yemendzhiev, H. Microbial degradation of phenol and phenolic derivatives. Eng. Life Sci. 2013, 13, 76-87. [CrossRef]

14. Tsai, S.-C.; Li, Y.-K. Purification and characterization of a catechol 1,2-dioxygenase from a phenol degrading Candida albicans TL3. Arch. Microbiol. 2007, 187, 199-206. [CrossRef] [PubMed]

15. Al-Hakim, M.H.; Hasan, R.; Ali, M.H.; Rabbee, M.F.; Marufatuzzahan, H.M.; Joy, Z.F. In-silico characterization and homology modeling of catechol 1,2 dioxygenase involved in processing of catechol- an intermediate of aromatic compound degradation pathway. Glob. J. Sci. Front. Res. G Bio-Tech Genet. 2015, 15, 1-13.

16. Bhat, M.A.; Ishida, T.; Horiike, K.; Vaidyanathan, C.S.; Nozaki, M. Purification of 3,5-dichlorocatechol 1,2-dioxygenase, a nonheme iron dioxygenase and a key enzyme in the biodegradation of a herbicide, 2,4-dichlorophenoxyacetic acid (2,4-D), from Pseudomonas cepacia CSV90. Arch. Biochem. Biophys. 1993, 300, 738-746. [CrossRef] [PubMed]

17. Lofrano, G.; Rizzo, L.; Grassi, M.; Belgiorno, V. Advanced oxidation of catechol: A comparison among photocatalysis, Fenton and photo-Fenton processes. Desalination 2009, 249, 878-883. [CrossRef]

18. Subramanyam, R.; Mishra, I.M. Biodegradation of catechol (2-hydroxy phenol) bearing wastewater in an UASB reactor. Chemosphere 2007, 69, 816-824. [CrossRef] [PubMed]

19. Titus, G.P.; Mueller, H.A.; Burgner, J.; Rodríguez de Córdoba, S.; Peñalva, M.A.; Timm, D.E. Crystal structure of human homogentisate dioxygenase. Nat. Struct. Biol. 2000, 7, 542. [PubMed] 
20. Cha, C.-J. Catechol 1,2-dioxygenase from Rhodococcus rhodochrous N75 capable of metabolizing alkyl-substituted catechols. J. Microbiol. Biotechnol. 2006, 16, 778-785.

21. Nadaf, N.; Ghosh, J. Purification and characterization of catechol 1,2-dioxygenase from Rhodococcus sp. NCIM 2891. Res. J. Environ. Earth Sci. 2011, 3, 608-613.

22. Lin, J.; Milase, R.N. Purification and characterization of catechol 1,2-dioxygenase from Acinetobacter sp. Y64 strain and Escherichia coli transformants. Protein J. 2015, 34, 421-433. [CrossRef] [PubMed]

23. Guzik, U.; Greń, I.; Hupert-Kocurek, K.; Wojcieszyńska, D. Catechol 1,2-dioxygenase from the new aromatic compounds-Degrading Pseudomonas putida strain N6. Int. Biodeterior. Biodegrad. 2011, 65, 504-512. [CrossRef]

24. Wang, C.-L.; You, S.-L.; Wang, S.-L. Purification and characterization of a novel catechol 1,2-dioxygenase from Pseudomonas aeruginosa with benzoic acid as a carbon source. Process Biochem. 2006, 41, 1594-1601. [CrossRef]

25. Guzik, U.; Hupert-Kocurek, K.; Sitnik, M.; Wojcieszyńska, D. High activity catechol 1,2-dioxygenase from Stenotrophomonas maltophilia strain KB2 as a useful tool in cis, cis-muconic acid production. Antonie Van Leeuwenhoek 2013, 103, 1297-1307. [CrossRef] [PubMed]

26. Solyanikova, I.P.; Konovalova, E.I.; Golovleva, L.A. Methylcatechol 1,2-dioxygenase of Rhodococcus opacus 6a is a new type of the catechol-cleaving enzyme. Biochemistry 2009, 74, 994-1001. [CrossRef] [PubMed]

27. Pandeeti, E.V.P.; Siddavattam, D. Purification and characterization of catechol 1,2-dioxygenase from Acinetobacter sp. DS002 and cloning, sequencing of partial catA gene. Indian J. Microbiol. 2011, 51, 312-318. [CrossRef] [PubMed]

28. Stoilova, I.; Krastanov, A.; Stanchev, V.; Daniel, D.; Gerginova, M.; Alexieva, Z. Biodegradation of high amounts of phenol, catechol, 2,4-dichlorophenol and 2,6-dimethoxyphenol by Aspergillus awamori cells. Enzyme Microb. Technol. 2006, 39, 1036-1041. [CrossRef]

29. Pakala, S.B.; Gorla, P.; Pinjari, A.B.; Krovidi, R.K.; Baru, R.; Yanamandra, M.; Merrick, M.; Siddavattam, D. Biodegradation of methyl parathion and p-nitrophenol: Evidence for the presence of a p-nitrophenol 2-hydroxylase in a Gram-negative Serratia sp. strain DS001. Appl. Microbiol. Biotechnol. 2007, 73, 1452-1462. [CrossRef]

30. Jeoung, J.-H.; Bommer, M.; Lin, T.-Y.; Dobbek, H. Visualizing the substrate-, superoxo-, alkylperoxo-, and product-bound states at the nonheme Fe (II) site of homogentisate dioxygenase. Proc. Natl. Acad. Sci. USA 2013, 110, 12625-12630. [CrossRef]

31. Mendez, V.; Agullo, L.; Gonzalez, M.; Seeger, M. The homogentisate and homoprotocatechuate central pathways are involved in 3- and 4-hydroxyphenylacetate degradation by Burkholderia xenovorans LB400. PLoS ONE 2011, 6, e17583. [CrossRef] [PubMed]

32. Olaniran, A.O.; Singh, L.; Kumar, A.; Mokoena, P.; Pillay, B. Aerobic degradation of 2,4-dichlorophenoxyacetic acid and other chlorophenols by Pseudomonas strains indigenous to contaminated soil in South Africa: Growth kinetics and degradation pathway. Appl. Biochem. Microbiol. 2017, 53, 209-216. [CrossRef]

33. Marchesi, J.R.; Sato, T.; Weightman, A.J.; Martin, T.A.; Fry, J.C.; Hiom, S.J.; Wade, W.G. Design and evaluation of useful bacterium-specific PCR primers that amplify genes coding for bacterial 16S rRNA. Appl. Environ. Microbiol. 1998, 64, 795-799. [PubMed]

34. Kumar, A.; Khan, F.I.; Olaniran, A.O. Chloroacetaldehyde dehydrogenase from Ancylobacter aquaticus UV5: Cloning, expression, characterization and molecular modeling. Int. J. Biol. Macromol. 2018, 114, 1117-1126. [CrossRef] [PubMed]

35. Fernández-Cañón, J.M.; Peñalva, M.A. Spectrophotometric determination of homogentisate using Aspergillus nidulans homogentisate dioxygenase. Anal. Biochem. 1997, 245, 218-221. [CrossRef] [PubMed]

36. Borowski, T.; Georgiev, V.; Siegbahn, P.E.M. Catalytic reaction mechanism of homogentisate dioxygenase: A hybrid DFT study. J. Am. Chem. Soc. 2005, 127, 17303-17314. [CrossRef] [PubMed]

(C) 2018 by the authors. Licensee MDPI, Basel, Switzerland. This article is an open access article distributed under the terms and conditions of the Creative Commons Attribution (CC BY) license (http://creativecommons.org/licenses/by/4.0/). 